\title{
Physiological and hematological parameters of sheep reared in the tropics and subtropics
}

[Parâmetros fisiológicos e hematológicos de ovinos criados nos trópicos e nos subtrópicos]

\author{
L. Seixas ${ }^{1}$, V.Peripolli2 ${ }^{*}$, D. A.E. Façanha ${ }^{3}$, V. Fischer ${ }^{4}$, C.H.E.C. Poli ${ }^{4}$, \\ C.B. Melo ${ }^{1}$, H. Louvandini ${ }^{5}$, C.M. McManus ${ }^{1}$ \\ ${ }^{1}$ Universidade de Brasília - Brasília, DF \\ ${ }^{2}$ Instituto Federal Catarinense - Campus Araquari - Araquari, SC \\ ${ }^{3}$ Universidade Federal Rural do Semi-árido - Mossoró, RN \\ ${ }^{4}$ Universidade Federal do Rio Grande do Sul - Porto Alegre, RS \\ ${ }^{5}$ Centro de Energia Nuclear na Agricultura - Universidade de São Paulo - Piracicaba, SP
}

\begin{abstract}
This study aimed to determine the physiological and hematological parameters of sheep in Brazil. Therefore, 5,081 observations were used from previous experiments with animals from different Brazilian regions with the time of day, gender, breed, age, physiological characteristics, hematological and climatic variables. The animals were classified according to their stress level, and only data of non-stressed animals were used to calculate the reference values. Respiratory rate was the parameter that most differed from the normal range, with values above the limits usually reported for the species, being higher in commercial wool sheep. For hematological variables, differences were observed between the present results and the previously reported values in the literature. A higher number of red blood cells (RBC), lower hemoglobin and mean corpuscular hemoglobin concentration (MCHC) were observed in young animals. A higher number of RBC and MCHC were noted in sheep crossed with local breeds. Considering that physiological and hematological parameters are indicators of the animal's pathological or physiological state, for a correct interpretation of the results, the use of reference values based on animals with similar racial characteristics and subjected to similar environmental conditions is recommended.
\end{abstract}

Keywords: hematology, rectal temperature, reference interval, respiratory rate, small ruminants

\section{RESUMO}

O objetivo deste estudo foi determinar parâmetros fisiológicos e hematológicos de ovinos no Brasil. Portanto, foram utilizadas 5.081 observações de experimentos anteriores com animais de diversas regiões do Brasil, com diferentes horário, sexo, raça, idade, características fisiológicas, variáveis hematológicas e climáticas. Os animais foram classificados de acordo com o nível de estresse, e apenas os dados dos animais não estressados foram utilizados para o cálculo dos valores de referência. A frequência respiratória foi o parâmetro que mais diferiu em relação à normalidade, com valores acima dos limites usualmente relatados para a espécie, sendo maior em ovinos de lã comercial. Para as variáveis hematológicas, também foram verificadas diferenças entre os resultados observados e os valores previamente relatados na literatura. Maior número de hemácias, menor hemoglobina e concentração de hemoglobina corpuscular média (CHbCM) foram observados em animais jovens e maior número de hemácias e CHbCM em ovinos cruzados com raças locais. Considerando que os parâmetros fisiológicos e hematológicos são indicadores do estado patológico ou fisiológico do animal, para uma correta interpretação dos resultados recomenda-se a utilização de valores de referência baseados em animais com características raciais semelhantes e submetidos a condições ambientais também semelhantes.

Palavras-chave: frequência respiratória, hematologia, intervalo de referência, pequenos ruminantes, temperatura retal

Recebido em 2 de outubro de 2020

Aceito em 24 de fevereiro de 2021

*Autor para correspondência (corresponding author)

E-mail: vanessa.peripolli@hotmal.com 


\section{INTRODUCTION}

Changes in physiological parameters, biochemical and hematological constituents are important indicators of the animal's physiological or pathological state (Ahmad et al., 2003). For a correct interpretation of the results, it is necessary to consider the influence of regional factors, such as climatic and environmental conditions, breed and age (Jain, 1993). Researchers have reported an increase in some blood parameters such as the number of red blood cells and hemoglobin concentration with age development (David et al., 2012). Variation concerning genetic groups has also been reported (Correa et al., 2012). A study with Morada Nova sheep observed average red blood cell count values and hematocrit higher than those reported in the literature for small ruminants (Chaves et al., 2009).

The reference intervals are based on the values that occur in $95 \%$ of the healthy population (Vojta et al., 2011), and 5\% of individuals may have blood count values outside the reference range. Therefore, small variations do not necessarily indicate any disturbance (Resende et al., 2013). A study carried out in Croatia found that the reference values used in the literature were inappropriate, and the calculation of specific confidence intervals for each geographical region is recommended (Šimpraga et al., 2013). Thus, the interpretation of the results depends on precise reference intervals that represent the studied population.

Considering that the reference values used are based on data from temperate animals and that animals in Brazil are subjected to environmental stressors different from those found in temperate regions, the use of reference tables with data from these regions may not be adequate to the Brazilian reality. Differences can also be seen between hair and wool sheep (McManus et al., 2020), and under climate change, the correct interpretation of these parameters is essential for animal management. Therefore, it is crucial to determine the standard parameters for non-stressed animals raised in the country, building a reference table with local data to make the comparison correctly. Thus, the present study aimed to define blood and physiological parameters for sheep in Brazil.

\section{MATERIAL AND METHODS}

A spreadsheet was prepared with 5,081 observations from previous trials carried out with sheep in the south, center-west and northeast regions (Rio Grande do Sul, Distrito Federal, Goiás and Rio Grande do Norte states) (Table 1). Data included the time of day, gender, breed, physiological, hematological characteristics and climatic variables (temperature and relative humidity). Based on climatic data, the Temperature and Humidity Index (THI) was calculated based on the equation below, where $\mathrm{Tdb}$ - is Dry Bulb Temperature and Twb - Wet Bulb temperature, according to Thom (1959):

$\mathrm{THI}=[0.4 \times(\mathrm{Tdb}+\mathrm{Twb})] \times 1.8+32+15$

The physiological and blood parameters evaluated were rectal temperature (RT), respiratory rate (RF), heart rate (HR), number of red blood cells (RBC), hematocrit (HT), hemoglobin concentration (HGB), mean corpuscular volume (MCV), mean corpuscular hemoglobin concentration (MCHC), number of white blood cell (WBC), monocytes (MONO), lymphocytes (LYM), eosinophils (EOSI), segmented neutrophils (SEGM), platelets (PLAT), total plasma protein (TPP), and fibrinogen (FIBRI). The animals were divided into groups by age: adult (equal to or over 365 days) and young (less than 365 days). Due to the variety of breeds, these were grouped into types: commercial wool (CW), local hair $(\mathrm{LH})$ and crossed with hair $(\mathrm{CH})$.

The animals were also classified according to the stress level, being considered THI stressor above 70 and non-stressful THI equal to or below 70 (Hahn et al., 2009). For the calculation of the means of the hematological and physiological parameters, only non-stressed animals were considered. Therefore, age and type factors were considered for the calculation. The analyses were performed using the statistical program SAS 9.3 (Statistical Analysis Institute, Cary, North Carolina) with a significance level of $5 \%$. The PROC GLM was used fitting THI as a covariable, age group and sheep type as fixed effects, and experiment and locality as random effects. 
Table 1. The number of trials carried out with sheep by type, breed and location (regions) in Brazil

\begin{tabular}{|c|c|c|c|c|}
\hline Type & Breed & north east & center-west & south \\
\hline \multirow{3}{*}{ Hair } & Santa Inês & & 10 & 1 \\
\hline & Dorper & & 2 & 1 \\
\hline & Morada Nova & 1 & 2 & \\
\hline \multirow{10}{*}{ Commercial Wool } & Ile de France & & 3 & 2 \\
\hline & Texel & & 2 & 2 \\
\hline & Bergamacia & & 3 & \\
\hline & Hampshire Down & & 2 & 1 \\
\hline & Suffolk & & & 2 \\
\hline & Corriedale & & & 2 \\
\hline & Crioula Lanada & & & 2 \\
\hline & Ideal & & & 2 \\
\hline & Merino & & & 1 \\
\hline & Romney Marsh & & & 1 \\
\hline \multirow{9}{*}{ Crossbreds } & Dorper x Santa Inês & & 2 & \\
\hline & Ile de France x Santa Inês & & 2 & \\
\hline & East Friesian x Santa Inês & & 2 & \\
\hline & Poll Dorset x Dorper & & 2 & \\
\hline & Poll Dorset x Santa Inês & & 2 & \\
\hline & Poll Dorset x White Dorper & & 1 & \\
\hline & Dorper x Santa Inês & & 2 & \\
\hline & Texel x Santa Inês & & 1 & \\
\hline & Texel x Dorper & & 2 & \\
\hline
\end{tabular}

\section{RESULTS}

In general, although the means of the studied parameters are in agreement with the reference values, the values of the 2.5 and 97.5 percentiles that indicate the lower and upper limits, respectively, diverged from those pre-established in the literature (Jain, 1993; Reece and Swenson, 2004) (Tables 2 and 3). The respiratory rate was the parameter that most diverged from literature. All mean values and reference intervals well above the normal limits for the species in all types and age groups. Likewise, upper and lower heart rate limits were also not coincident with the reference values. In $\mathrm{CW}$ adults, the average heart rate was also higher than the intervals mentioned in the literature.

The maximum values for rectal temperatures of the adult $\mathrm{CW}$ and $\mathrm{LH}$ types and of all types of young sheep were also higher than the values considered normal. Regarding the erythrogram, the hematocrit's lower and upper limits were lower than the reference values (Jain, 1993), and the 2.5 percentile was outside the normal range. In general, the minimum values for the number of red blood cells and the concentration of hemoglobin of all types and age groups also differed from the reference values. In contrast, in young animals, the means of hemoglobin concentration of all types were lower than the reference interval.

Regarding the average qualitative characteristics, the maximum and minimum values of the MCV and $\mathrm{MCHC}$ of the adult LH sheep, and the average of the $\mathrm{MCHC}$ of the adult $\mathrm{CH}$ were different from the literature. In young animals, the mean as well as maximum and minimum limits of MCV and $\mathrm{MCHC}$ were lower than the normal ranges in all types. The total plasma protein values of the 2.5 and 97.5 percentiles of adult $\mathrm{CH}$ and $\mathrm{LH}$ types were lower and higher than the reference limits (Jain, 1993), respectively.

In the leukogram, there were also differences between the results and the values cited in the literature Although the average number of WBC was within the reference range, the maximum and minimum limits were divergent, with values below and above the pre-established limits being observed in all types and age groups, except for $\mathrm{CH}$ adults whose 2.5 percentile was higher. 
Physiological and hematological...

Table 2. Least squares means of physiological and blood parameters for adult sheep (over one year old) in Brazil

\begin{tabular}{|c|c|c|c|c|c|c|}
\hline & $\mathrm{N}$ & Mean & Standard Deviation & $2.50 \%$ & $97.50 \%$ & Reference Values* \\
\hline \multicolumn{7}{|l|}{$\mathrm{CH}$} \\
\hline RT & 167 & 38.12 & 0.40 & 37.30 & 39.10 & $38.3-39.9^{\circ} \mathrm{C}$ \\
\hline $\mathrm{RR}$ & 167 & 67.44 & 49.24 & 20.00 & 204.00 & 20-34 mov. $\mathrm{min}^{-1}$ \\
\hline HR & - & - & - & - & - & $70-80$ beats. $\mathrm{min}^{-1}$ \\
\hline HT & 167 & 29.35 & 5.99 & 16.00 & 40.00 & $27-45 \%$ \\
\hline TPP & 167 & 6.93 & 0.69 & 4.90 & 8.10 & $6-7.5 \mathrm{~g} \cdot \mathrm{dL}^{-1}$ \\
\hline $\mathrm{RBC}$ & 167 & 8.65 & 1.69 & 5.41 & 11.55 & $9-15 \times 10^{6} \cdot \mu \mathrm{L}^{-1}$ \\
\hline HGB & 167 & 9.66 & 1.53 & 6.30 & 12.40 & $9-15 \mathrm{~g} \cdot \mathrm{dL}^{-1}$ \\
\hline WBC & 167 & 9.32 & 3.17 & 5.00 & 15.10 & $4-12 \times 10^{6} \cdot \mu \mathrm{L}^{-1}$ \\
\hline MONO & 167 & 1168.40 & 2377.08 & 110.00 & 7500.00 & $0-75010^{6} . \mathrm{L}^{-1}$ \\
\hline LYM & 167 & 2411.56 & 1194.70 & 988.00 & 5170 & $2000-900010^{6} \cdot \mathrm{L}^{-1}$ \\
\hline EOSI & 167 & 1308.83 & 1896.35 & 201.00 & 7500 & $0-100010^{6} \cdot \mathrm{L}^{-1}$ \\
\hline SEGM & 167 & 4980.11 & 2152.86 & 1700.00 & 10707 & $700-600010^{6} \cdot \mathrm{L}^{-1}$ \\
\hline PLAT & 167 & 464.96 & 242.47 & 148.00 & 1031 & $250-750 \times 10^{3} \cdot \mu \mathrm{L}^{-1}$ \\
\hline MCV & 167 & 30.57 & 1.52 & 29.00 & 34 & $28-40 \mathrm{fl}$ \\
\hline $\mathrm{MCHC}$ & 167 & 37.43 & 7.90 & 30.00 & 57.71 & $31-34 \%$ \\
\hline FIBRI & - & - & - & - & - & $0.1-0.5 \mathrm{~g} \cdot \mathrm{dL}^{-1}$ \\
\hline \multicolumn{7}{|l|}{$\mathrm{CW}$} \\
\hline RT & 1337 & 39.50 & 0.70 & 38.00 & 40.7 & $38.3-39.90^{\circ} \mathrm{C}$ \\
\hline $\mathrm{RR}$ & 1337 & 81.40 & 44.66 & 24.00 & 192 & 20-34 mov. $\mathrm{min}^{-1}$ \\
\hline HR & 1337 & 113.51 & 47.21 & 64.00 & 272 & $70-80$ beats. $\mathrm{min}^{-1}$ \\
\hline HT & 1337 & 30.78 & 4.98 & 22.00 & 40 & $27-45 \%$ \\
\hline TPP & 1337 & 7.52 & 0.74 & 6.40 & 9.2 & $6-7.5 \mathrm{~g} \cdot \mathrm{dL}^{-1}$ \\
\hline $\mathrm{RBC}$ & 1337 & 8.81 & 1.32 & 6.19 & 11.2 & $9-15 \times 10^{6} \cdot \mu \mathrm{L}^{-1}$ \\
\hline HGB & 1337 & 9.70 & 1.45 & 6.70 & 12.5 & $9-15 \mathrm{~g} . \mathrm{dL}^{-1}$ \\
\hline WBC & 1337 & 8.75 & 3.14 & 2.16 & 14.6 & $4-12 \times 10^{6} \cdot \mu \mathrm{L}^{-1}$ \\
\hline MONO & 1337 & 1966.26 & 3046.14 & 104.00 & 9300 & $0-75010^{6} \cdot \mathrm{L}^{-1}$ \\
\hline LYM & 1337 & 3624.22 & 1396.91 & 1612 & 6555 & $2000-900010^{6} . \mathrm{L}^{-1}$ \\
\hline EOSI & 1337 & 1276.45 & 2058.44 & 110 & 8500 & $0-100010^{6} \cdot \mathrm{L}^{-1}$ \\
\hline SEGM & 1337 & 5039.82 & 3585.93 & 1014 & 16456 & $700-600010^{6} \cdot \mathrm{L}^{-1}$ \\
\hline PLAT & 1337 & 468.18 & 225.69 & 87 & 963 & $250-750 \times 10^{3} \cdot \mu \mathrm{L}^{-1}$ \\
\hline $\mathrm{MCV}$ & 1337 & 32.85 & 1.57 & 31 & 37 & $28-40 \mathrm{fl}$ \\
\hline $\mathrm{MCHC}$ & 1337 & 33.53 & 2.18 & 30 & 40.31 & $31-34 \%$ \\
\hline FIBRI & - & - & - & - & - & $0.1-0.5 \mathrm{~g} \cdot \mathrm{dL}^{-1}$ \\
\hline \multicolumn{7}{|l|}{ LH } \\
\hline RT & 1077 & 38.68 & 0.81 & 37.1 & 40.3 & $38.3-39.90^{\circ} \mathrm{C}$ \\
\hline RR & 1077 & 46.19 & 22.77 & 20 & 104 & 20-34 mov. min $^{-1}$ \\
\hline HR & 1077 & 75.53 & 39.74 & 20 & 140 & $70-80$ beats. $\mathrm{min}^{-1}$ \\
\hline HT & 1077 & 28.98 & 5.71 & 15 & 38 & $27-45 \%$ \\
\hline TPP & 1077 & 6.82 & 0.87 & 4.2 & 8.4 & $6-7.5 \mathrm{~g} . \mathrm{dL}^{-1}$ \\
\hline $\mathrm{RBC}$ & 1077 & 9.97 & 2.11 & 5.3 & 14.1 & $9-15 \times 10^{6} \cdot \mu \mathrm{L}^{-1}$ \\
\hline HGB & 1077 & 9.40 & 1.61 & 4.7 & 12 & $9-15 \mathrm{~g} . \mathrm{dL}^{-1}$ \\
\hline WBC & 1077 & 9.60 & 3.69 & 2.24 & 18 & $4-12 \times 10^{6} \cdot \mu \mathrm{L}^{-1}$ \\
\hline MONO & 1077 & 3234.33 & 3740.25 & 142 & 9300 & $0-75010^{6} \cdot \mathrm{L}^{-1}$ \\
\hline LYM & 1077 & 2781.17 & 1017.27 & 702 & 4557 & $2000-900010^{6} \cdot \mathrm{L}^{-1}$ \\
\hline EOSI & 1077 & 368.06 & 246.62 & 142 & 1089 & $0-100010^{6} \cdot \mathrm{L}^{-1}$ \\
\hline SEGM & 1077 & 4615.17 & 1177.99 & 3139 & 7560 & $700-600010^{6} \cdot \mathrm{L}^{-1}$ \\
\hline PLAT & 1077 & 734.36 & 256.35 & 285 & 1280 & $250-750 \times 10^{3} \cdot \mu \mathrm{L}^{-1}$ \\
\hline $\mathrm{MCV}$ & 1077 & 33.05 & 5.99 & 23.52 & 48.19 & 28-40fl \\
\hline $\mathrm{MCHC}$ & 1077 & 32.09 & 4.41 & 25.7 & 41.19 & $31-34 \%$ \\
\hline FIBRI & 1077 & 0.35 & 0.17 & 0.1 & 0.68 & $0.1-0.5 \mathrm{~g} . \mathrm{dL}^{-1}$ \\
\hline
\end{tabular}

$\mathrm{N}=$ number of observations; $\mathrm{CH}=$ crossing with naturalized; $\mathrm{CW}=$ commercial wool; $\mathrm{LH}=$ local hair; $\mathrm{RT}=$ rectal temperature; $\mathrm{RR}=$ respiratory rate $\mathrm{HR}=$ heart rate; $\mathrm{HT}=$ hematocrit $; \mathrm{TPP}=$ total plasma protein $; \mathrm{RBC}=$ red blood cells; $\mathrm{HGB}=$ hemoglobin; $\mathrm{WBC}=$ white blood cell; $\mathrm{MONO}=$ monocytes; $\mathrm{LYM}=$ lymphocytes; $\mathrm{EOSI}=$ eosinophils; SEGM = segmented; PLAT $=$ platelets; $\mathrm{MCV}=$ mean corpuscular volume; $\mathrm{MCHC}=$ average globular hemoglobin concentration; FIBRI = fibrinogen; - = no data. *(Reece and Swenson, 2004); Jain (1993). 
Seixas et al.

Table 3. Least squares means of physiological and blood parameters for young sheep (under one year old) in Brazil

\begin{tabular}{|c|c|c|c|c|c|c|}
\hline & $\mathrm{N}$ & Mean & Standard Deviation & $2.50 \%$ & $97.50 \%$ & Reference Values* \\
\hline \multicolumn{7}{|l|}{$\mathrm{CH}$} \\
\hline RT & 1040 & 39.35 & 0.66 & 38.09 & 40.5 & $38.3-39.9^{\circ} \mathrm{C}$ \\
\hline RR & 1040 & 70.37 & 51.91 & 20 & 176 & 20-34 mov. $\min ^{-1}$ \\
\hline HR & 1040 & 74.40 & 12.81 & 56 & 108 & $70-80$ beats. $\mathrm{min}^{-1}$ \\
\hline HT & 1040 & 28.10 & 3.66 & 20.5 & 33.8 & $27-45 \%$ \\
\hline ТPP & 1040 & 6.00 & 0.23 & 5.8 & 6.2 & $6-7.5 \mathrm{~g} \cdot \mathrm{dL}^{-1}$ \\
\hline $\mathrm{RBC}$ & 1040 & 11.80 & 1.42 & 9.16 & 14.26 & $9-15 \times 10^{6} \cdot \mu \mathrm{L}^{-1}$ \\
\hline HGB & 1040 & 8.13 & 1.32 & 5.8 & 9.8 & $9-15 \mathrm{~g} \cdot \mathrm{dL}^{-1}$ \\
\hline WBC & 1040 & 7.47 & 2.54 & 3.44 & 13.6 & $4-12 \times 10^{6} \cdot \mu \mathrm{L}^{-1}$ \\
\hline MONO & 1040 & 1127.19 & 2212.82 & 100 & 8400 & $0-75010^{6} . \mathrm{L}^{-1}$ \\
\hline LYM & 1040 & 2844.04 & 1198.34 & 930 & 5400 & $2000-900010^{6} \cdot \mathrm{L}^{-1}$ \\
\hline EOSI & 1040 & 645.92 & 497.63 & 138 & 1904 & 0-1000 $10^{6} . \mathrm{L}^{-1}$ \\
\hline SEGM & 1040 & 4166.43 & 3137.25 & 1040 & 16215 & $700-600010^{6} . \mathrm{L}^{-1}$ \\
\hline PLAT & 1040 & 196.13 & 68.42 & 134 & 349 & $250-750 \times 10^{3} \cdot \mu \mathrm{L}^{-1}$ \\
\hline $\mathrm{MCV}$ & 1040 & 23.74 & 1.57 & 21.3 & 26.3 & $28-40 \mathrm{fl}$ \\
\hline $\mathrm{MCHC}$ & 1040 & 29.00 & 2.11 & 26.8 & 33.5 & $31-34 \%$ \\
\hline FIBRI & 1040 & 0.32 & 0.16 & 0.1 & 0.6 & $0.1-0.5 \mathrm{~g} \cdot \mathrm{dL}^{-1}$ \\
\hline \multicolumn{7}{|l|}{$\mathrm{CW}$} \\
\hline RT & 545 & 39.67 & 0.67 & 38.29 & 40.6 & $38.3-39.9^{\circ} \mathrm{C}$ \\
\hline RR & 545 & 82.18 & 56.02 & 20 & 180 & 20-34 mov. min $^{-1}$ \\
\hline HR & 545 & 72.92 & 14.39 & 56 & 120 & $70-80$ beats. $\min ^{-1}$ \\
\hline HT & 545 & 28.94 & 4.45 & 15.6 & 39.4 & $27-45 \%$ \\
\hline TPP & 545 & - & - & - & - & $6-7.5 \mathrm{~g} . \mathrm{dL}^{-1}$ \\
\hline RBC & 545 & 12.21 & 1.84 & 6.66 & 16.49 & $9-15 \times 10^{6} \cdot \mu \mathrm{L}^{-1}$ \\
\hline HGB & 545 & 8.53 & 1.46 & 4.5 & 10.8 & $9-15 \mathrm{~g} \cdot \mathrm{dL}^{-1}$ \\
\hline WBC & 545 & 9.33 & 2.81 & 3.9 & 18.3 & $4-12 \times 10^{6} \cdot \mu \mathrm{L}^{-1}$ \\
\hline MONO & 545 & 1950.08 & 2846.29 & 100 & 8600 & $0-75010^{6} \cdot \mathrm{L}^{-1}$ \\
\hline LYM & 545 & 3500.65 & 1787.87 & 1287 & 7462.4 & $2000-900010^{6} \cdot \mathrm{L}^{-1}$ \\
\hline EOSI & 545 & 1651.09 & 3046.22 & 273 & 14080 & $0-100010^{6} \cdot \mathrm{L}^{-1}$ \\
\hline SEGM & 545 & 8644.04 & 14867.23 & 1989 & 66105 & $700-600010^{6} . \mathrm{L}^{-1}$ \\
\hline PLAT & 545 & 194.72 & 70.43 & 87 & 328 & $250-750 \times 10^{3} \cdot \mu \mathrm{L}^{-1}$ \\
\hline $\mathrm{MCV}$ & 545 & 23.70 & 1.51 & 21.3 & 26.6 & $28-40 \mathrm{fl}$ \\
\hline $\mathrm{MCHC}$ & 545 & 29.49 & 1.58 & 27.2 & 32.8 & $31-34 \%$ \\
\hline FIBRI & 545 & 0.37 & 0.24 & 0.1 & 0.8 & $0.1-0.5 \mathrm{~g} \cdot \mathrm{dL}^{-1}$ \\
\hline \multicolumn{7}{|l|}{$\mathrm{LH}$} \\
\hline RT & 915 & 39.20 & 1.04 & 36.7 & 40.5 & $38.3-39.9^{\circ} \mathrm{C}$ \\
\hline $\mathrm{RR}$ & 915 & 74.53 & 53.98 & 16 & 176 & 20-34 mov.min ${ }^{-1}$ \\
\hline HR & 915 & 74.63 & 16.39 & 60 & 120 & $70-80$ beats. $\min ^{-1}$ \\
\hline HT & 915 & 31.50 & 5.68 & 12.6 & 39 & $27-45 \%$ \\
\hline TPP & - & - & - & - & - & $6-7.5 \mathrm{~g} \cdot \mathrm{dL}^{-1}$ \\
\hline $\mathrm{RBC}$ & 915 & 12.96 & 1.94 & 6.03 & 15.07 & $9-15 \times 10^{6} \cdot \mu \mathrm{L}^{-1}$ \\
\hline HGB & 915 & 8.96 & 1.50 & 3.5 & 11 & $9-15 \mathrm{~g} \cdot \mathrm{dL}^{-1}$ \\
\hline WBC & 915 & 8.45 & 3.08 & 4.7 & 15.7 & $4-12 \times 10^{6} \cdot \mu \mathrm{L}^{-1}$ \\
\hline MONO & 915 & 389.83 & 220.43 & 158 & 942 & $0-75010^{6} \cdot \mathrm{L}^{-1}$ \\
\hline LYM & 915 & 3276.42 & 1266.41 & 940 & 4940 & $2000-900010^{6} . \mathrm{L}^{-1}$ \\
\hline EOSI & 915 & 766.42 & 459.73 & 188 & 1659 & $0-100010^{6} . \mathrm{L}^{-1}$ \\
\hline SEGM & 915 & 4334.58 & 1922.33 & 2013 & 8949 & $700-600010^{6} \cdot \mathrm{L}^{-1}$ \\
\hline PLAT & 915 & 195.71 & 57.31 & 112 & 328 & $250-750 \times 10^{3} \cdot \mu \mathrm{L}^{-1}$ \\
\hline MCV & 915 & 23.88 & 1.15 & 20.9 & 25.9 & $28-40 \mathrm{fl}$ \\
\hline $\mathrm{MCHC}$ & 915 & 28.84 & 1.07 & 26.9 & 31 & $31-34 \%$ \\
\hline FIBRI & 915 & 0.38 & 0.19 & 0.2 & 0.6 & $0.1-0.5 \mathrm{~g} \cdot \mathrm{dL}^{-1}$ \\
\hline
\end{tabular}

$\mathrm{N}=$ number of observations; $\mathrm{CH}=$ crossing with naturalized; $\mathrm{CW}=$ commercial wool; $\mathrm{LH}=$ local hair; $\mathrm{RT}=$ rectal temperature; $\mathrm{RR}=$ respiratory rate $\mathrm{HR}=$ heart rate; $\mathrm{HT}=$ hematocrit $\mathrm{TPP}=$ total plasma protein $; \mathrm{RBC}=$ red blood cells; $\mathrm{HGB}=$ hemoglobin; $\mathrm{WBC}=$ white blood cell; $\mathrm{MONO}=$ monocytes; $\mathrm{LYM}=$ lymphocytes; $\mathrm{EOSI}=$ eosinophils; SEGM = segmented; PLAT $=$ platelets; $\mathrm{MCV}=$ mean corpuscular volume; $\mathrm{MCHC}=$ average globular hemoglobin concentration; FIBRI = fibrinogen; - = no data. *(Reece and Swenson, 2004); Jain (1993). 
The average number of monocytes was greater than the upper limit mentioned in the literature in all types and age groups. The same was observed for the number of eosinophils in adult and young adult and adult $\mathrm{CH}$. In general, the means of the number of lymphocytes and segmented neutrophils were in accordance with the literature (Jain, 1993). However, the values of the 2.5 and 97.5 percentiles were different. As for the number of platelets, mean values were lower than the normal reported ranges in young animals.

There was a significant influence of type and age on physiological and hematological parameters (Tables 4 and 5). LH adult sheep had lower respiratory and heart rates, while higher rectal temperatures and respiratory rates were observed in CW animals. Regarding the difference between the age groups within each type, a higher rectal temperature was observed in young animals of all types and a higher respiratory rate in young $\mathrm{LH}$.

The young LH sheep had a higher HT for the hematological parameters, with no significant difference being observed between adults. Higher numbers of red blood cells, lower concentration of hemoglobin and MCHC were found in young animals, and $\mathrm{CH}$ had a higher number of red blood cells and MCHC. MCV was higher in adults and the LH type. Still, concerning adults, they also had higher TPP, PLAT and FIBRI. As for the type, a higher TPP and PLAT were found in the CW and $\mathrm{LH}$, respectively. In the leukogram analysis, the young $\mathrm{CH}$ sheep were those with the lowest WBC and the CWs the highest number of lymphocytes.

Table 4. Effect of the interaction between type and age for blood parameters on physiological and hematological parameters in sheep from Brazil

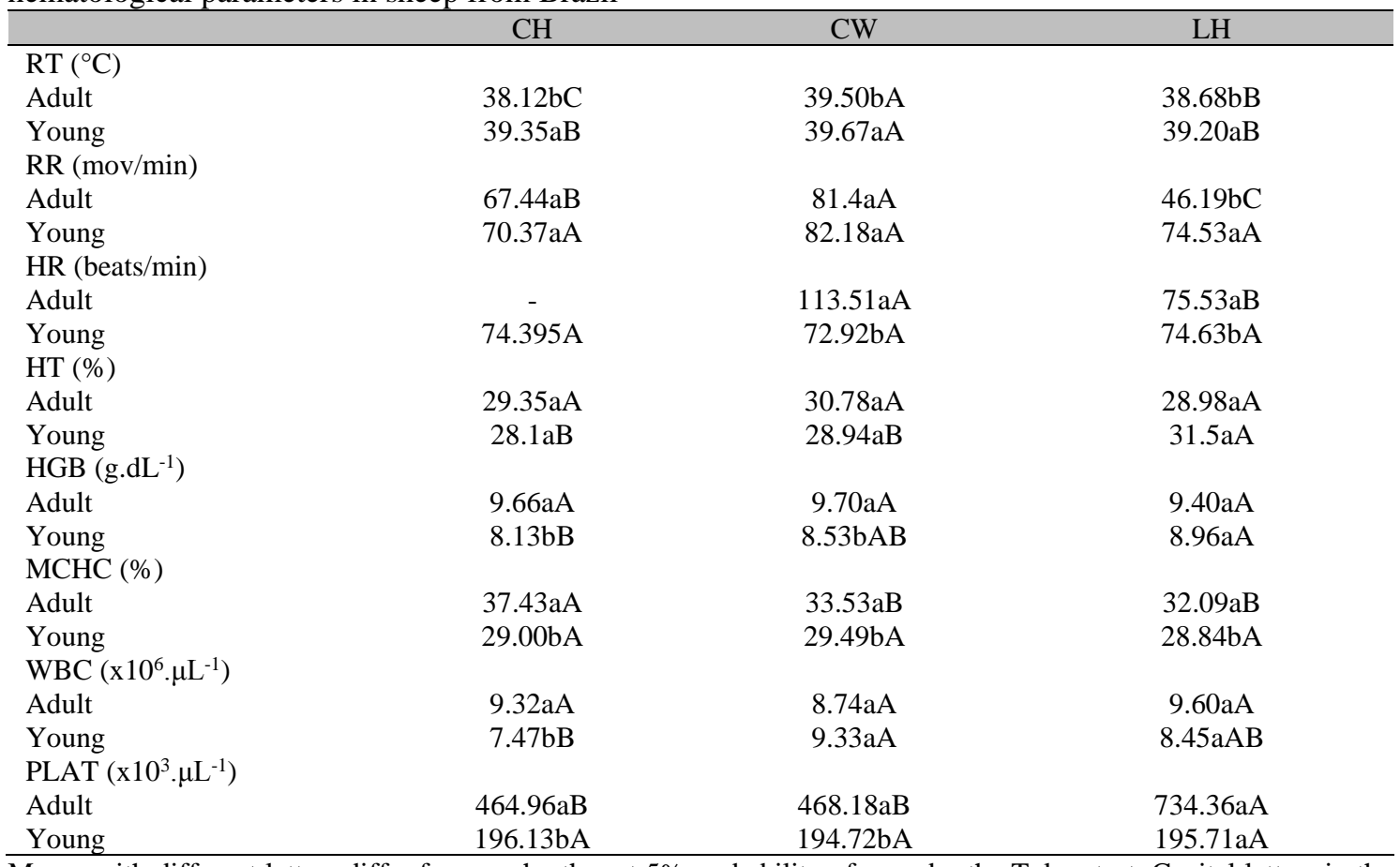

Means with different letters differ from each other at $5 \%$ probability of error by the Tukey test. Capital letters in the line and small in the column. $\mathrm{CH}=$ crossing with naturalized; $\mathrm{CW}=$ commercial wool; $\mathrm{LH}=$ local hair; $\mathrm{RT}=$ rectal temperature $\left({ }^{\circ} \mathrm{C}\right)$; RR $=$ respiratory rate $\left({\left.\text { mov. } \mathrm{min}^{-1}\right) ; \mathrm{HR}=\text { heart rate }(\text { Beats.min }}^{-1}\right) ; \mathrm{HT}=$ hematocrit $(\%)$; HGB = hemoglobin $\left(\mathrm{g} . \mathrm{dL}^{-1}\right)$; WBC $=$ white blood cells $\left(10^{6} \cdot \mu \mathrm{L}^{-1}\right)$; PLAT $=$ platelets $\left(10^{6} \cdot \mu \mathrm{L}^{-1}\right)$; MCHC $=$ average globular hemoglobin concentration $(\%) ;-=$ no data. 
Table 5. Average blood parameters for the type and age of sheep from Brazil

\begin{tabular}{lcccccccc}
\multicolumn{1}{c}{ Type } & TPP & RBC & MONO & LYM & SEGM & EOSI & MCV & FIBRI \\
\hline CH & $6.80 \mathrm{~b}$ & $11.42 \mathrm{a}$ & $1135.2 \mathrm{a}$ & $2747.9 \mathrm{~b}$ & $4347 \mathrm{a}$ & $800.9 \mathrm{ab}$ & $24.57 \mathrm{c}$ & $317.67 \mathrm{a}$ \\
CW & $7.51 \mathrm{a}$ & $10.43 \mathrm{~b}$ & $1961.5 \mathrm{a}$ & $3593.3 \mathrm{a}$ & $5941 \mathrm{a}$ & $1375.5 \mathrm{a}$ & $28.4979 \mathrm{~b}$ & $371.14 \mathrm{a}$ \\
LH & $6.82 \mathrm{~b}$ & $10.12 \mathrm{~b}$ & $1970.1 \mathrm{a}$ & $2979.3 \mathrm{~b}$ & $4503 \mathrm{a}$ & $527.4 \mathrm{~b}$ & $32.5651 \mathrm{a}$ & $350.23 \mathrm{a}$ \\
Age & & & & & & & & \\
Adult & $6.98 \mathrm{a}$ & $9.84 \mathrm{~b}$ & $2047.3 \mathrm{a}$ & $3281.6 \mathrm{a}$ & $5272.3 \mathrm{a}$ & $1118.8 \mathrm{a}$ & $32.9624 \mathrm{a}$ & $345.54 \mathrm{a}$ \\
Young & $6.08 \mathrm{~b}$ & $12.08 \mathrm{a}$ & $1238.4 \mathrm{~b}$ & $3055.6 \mathrm{a}$ & $4959.1 \mathrm{a}$ & $907.2 \mathrm{a}$ & $23.7498 \mathrm{~b}$ & $340 \mathrm{~b}$ \\
\hline
\end{tabular}

Means with different letters differ from each other at $5 \%$ probability of error by the Tukey test. $\mathrm{CH}=$ crossing with naturalized; $\mathrm{CW}=$ commercial wool; $\mathrm{LH}=$ local hair; $\mathrm{TPP}=$ total plasma protein $\left(\mathrm{g} . \mathrm{dL}^{-1}\right) ; \mathrm{RBC}=$ red blood cells; HGB $=$ hemoglobin $\left(\mathrm{g} \cdot \mathrm{dL}^{-1}\right)$; MONO = monocytes $\left(10^{6} \cdot \mu \mathrm{L}^{-1)} ; \mathrm{LYM}=\right.$ lymphocytes $\left(10^{6} \cdot \mu \mathrm{L}^{-1}\right)$; EOSI = eosinophils $\left(10^{6} . \mu \mathrm{L}^{-1}\right) ; \mathrm{SEGM}=$ segmented $\left(10^{6} . \mu \mathrm{L}^{-1}\right) ; \mathrm{MCV}=$ mean corpuscular volume $(\mathrm{fl}) ; \mathrm{FIBRI}=$ fibrinogen $\left(\mathrm{g} \cdot \mathrm{dL}^{-1}\right)$.

\section{DISCUSSION}

Blood parameters are used to assess animal health, as indicators of physiological changes, and influenced by factors such as species, gender, and age (Jain, 1993). Ribeiro et al., (2015) observed that the hematological parameters with greater power for discriminating two goat breeds' adaptive profile were the number of red blood cells, hematocrit and average corpuscular volume. Therefore, it is essential to determine precise reference intervals for these parameters to represent the studied population. As in the present study, Santana et al. (2009), when analyzing the complete blood count of young sheep, also found that the average values of the number of red blood cells were in accordance with the literature, and in both the minimum limit was lower than the "normal" range. Likewise, a study in Ceará with Morada Nova sheep observed that this parameter's mean was within the reference values (Chaves et al., 2009).

However, in this latter study, the intervals were not calculated. However, unlike the present study results, David et al. (2012) reported red cell averages in Santa Inês lambs below the normal range. It is worth mentioning that David et al. (2012) analyzed only animals from one location (west region of the state of São Paulo), while, in the present study, Santa Inês sheep from 11 trials located in the Midwest (Distrito Federal and Goiás) and the South (Rio Grande do Sul) were used. A divergence was observed concerning the average hemoglobin concentration in young animals, which is lower than the reference values. This corroborates with Correa et al. (2012) who also reported lower hemoglobin concentration in lambs and diverging from David et al. (2012) who observed averages of this parameter in young Santa Inês sheep in agreement with the literature.
The hematocrit means were within the confidence interval.

However, the minimum limits $(2.5 \%$ percentile $)$ were lower than this interval, similar to that verified by Santana et al. (2009). Likewise, hematocrit values have been reported in Santa Inês sheep outside the normal range for the species (Cardoso et al. 2011; David et al. 2012). Considering that, in sheep, hematocrit values below 24 are considered anemia (Polizopoulou, 2010), this difference between the results and the reference interval can lead to misdiagnosis.

In the present study, the number of red blood cells was higher in the younger rather than adult sheep, with the hemoglobin concentration being lower in this group and there was no significant difference for the hematocrit. This is in agreement with Yiğit et al. (2002), cited by Gama et al. (2007), who found that young sheep had higher mean values than adults for the number of red blood cells. As for the LH type, in which the Santa Inês breed is inserted, no significant difference was observed between the age groups for hemoglobin concentration and hematocrit. This corroborates in part with David et al. (2012). They also did not find any difference for the hematocrit in the sheep of this breed. Still, they reported a smaller number of red blood cells and hemoglobin concentration in the younger animals, suggesting an increase in blood parameters with age development. MCV averages were within normal limits. However, the maximum and minimum values of adult $\mathrm{LH}$ sheep were different from the literature. Chaves et al. (2009) and David et al. (2012) also observed mean MCV for naturalized sheep within the normal range, but these researchers did not check the upper and lower limits for this parameter. 
Regarding the differences between the genetic types, the $\mathrm{LH}$ and $\mathrm{CH}$ animals had higher and lower CMV, respectively, corroborating with Correa et al. (2012) who reported lower MCV in animals crossed with Texel and higher in Santa Inês breed. Regarding age, CMV decreases with age development (Jain, 1993). However, in the present study, lower MCV was found in young animals, unlike David et al. (2012) who reported higher value in the younger age group.

Among the genetic types, higher rectal temperatures were observed in European origin animals compared with those naturalized or crossed with naturalized. This corroborates with Marai et al. (2007) who stated that animals adapted to hot climates showed less variation in the parameters due to racial morphological and physiological adaptations that help in the dissipation of excess heat. Unlike the findings of the present study, in which a significant difference was found for rectal temperature in the two age groups, Lima et al. (2010) found no difference with advancing age for crossbred animals with Dorper. However, these authors only analyzed young animals, from 1 to 90 days old, whereas young and adult animals were compared in the present study.

The increase in heart rate increases superficial blood circulation, aiding heat dissipation. Thus, an increase in this parameter indicates a greater need for heat loss (Correa et al., 2012). In this study, this variable's mean was above the reference limits in adult $\mathrm{CW}$ sheep, and the maximum limits for all types and age groups were higher than usual standards. This is in agreement with McManus et al. (2009) who reported that even with mild temperatures during the morning, Santa Inês and Bergamascia sheep's heart rate was higher than $80 \mathrm{mov} / \mathrm{min}$. In the present study, this parameter was lower in adult LH sheep, corroborating with Correa et al. (2012), who reported a lower rate in Santa Inês animals.

\section{CONCLUSIONS}

Our study shows divergence with the average hemoglobin concentration in young animals, which is lower than the reference values. The hematocrit means were within the confidence interval, but the minimum limits $(2.5 \%$ percentile) were lower than this interval. Likewise, the hematocrit values have been reported in Santa
Inês sheep outside the species' normal range. The number of red blood cells was higher, and the hemoglobin concentration was lower in young sheep than adults. Also, we show the maximum and minimum values of adult $\mathrm{LH}$ sheep were different from the literature. Higher temperatures were observed in European origin animals compared with those that were naturalized or crossed with naturalized. Respiratory rate was the most diverged parameter, with the mean values and reference intervals well above the normal limits for the species in all types and age groups. Upper and lower heart rate limits were also not coincident with the reference values. In $\mathrm{CW}$ adults, the average heart rate was also higher than the intervals mentioned in the literature.

\section{ACKNOWLEDGEMENTS}

Thanks to the Brazilian National Council for Scientific and Technological Development (CNPq) and Coordination for the Improvement of Higher Education Personnel (CAPES) for scholarships and financing.

\section{REFERENCES}

AHMAD, I.; GOHAR, A.; AHMAD, N.; AHMAD, M. Haematological profile in cyclic, non cyclic and endomertitic cross-bred cattle. Int. J. Agric. Biol., v.5, p.332-334, 2003.

CARDOSO, E.C.; OLIVEIRA, D.R.; BALARO, M.F.A. et al. Índices produtivos e perfil metabólico de ovelhas Santa Inês no pós-parto no nordeste do Pará. Rev. Bras. Cienc. Vet., v.18, p.114-120, 2011.

CHAVES, D.; MORAIS, D.; VALE, A. et al. Parâmetros hematológicos e escore corporal de ovelhas da raça Morada Nova em ambiente quente. In: REUNIÃO ANUAL DA SOCIEDADE BRASILEIRA DE ZOOTECNIA, 46., 2009, Maringá. Anais... Maringá, 2009. p.1417. (Resumo).

CORREA, M.P.C.; CARDOSO, M.T.; CASTANHEIRA, M. et al. Heat tolerance in three genetic groups of lambs in central Brazil. Small Ruminannt Res., v.104, p.70-77, 2012.

DAVID, C.M.G.; LUQUETTI, B.C.; COSTA, R.L.D.D.; BONELLO, F.L. Padrão hematológico de cordeiros da raça santa Inês criados sob manejo semiextensivo na região oeste do estado de São Paulo. Bol. Ind. Anim., v.69, p.79-84, 2012. 
GAMA, S.; MATOS, J.; ZACHARIAS, F. et al. Dinâmica do eritrograma de cordeiros, resultantes do cruzamento entre animais de raças nativas criadas no Nordeste e a raça Dorper, desde o nascimento até os seis meses de idade. Rev. Bras. Saúde Prod. Anim., v.8, p.11-23, 2007.

HAHN, G.L.; GAUGHAN, J.B.; MADER, T.L.; EIGENBERG, R.A. Thermal indices and their applications for livestock environments. In: DESHAZER, J.A. (Ed.). Livestock energetics and thermal environmental management. St. Joseph: American Society of Agricultural and Biological Engineers, 2009. p.113-130.

JAIN, N.C. Essentials of veterinary hematology. New Jersey: Wiley, 1993. 417p.

LEPHERD, M.; CANFIELD, P.; HUNT, G.; BOSWARD, K. Haematological, biochemical and selected acute phase protein reference intervals for weaned female Merino lambs. Aust. Vet. J., v.87, p.5-11, 2009.

LIMA, C.C.V.; SILVA, D.F.M.; COSTA, J.N. et al. Parâmetros fisiológicos de cordeiros mestiços (1/2 e 3/4 Dorper) do nascimento até os 90 dias de idade. Rev. Bras. Saúde Prod. Anim., v.11, p.354361, 2010.

MARAI, I.; EL-DARAWANY, A.; FADIEL, A.; ABDEL-HAFEZ, M. Physiological traits as affected by heat stress in sheep-a review. Small Ruminant Res., v.71, p.1-12, 2007.

McMANUS, C.; PALUDO, G.; LOUVANDINI, H. et al. Heat tolerance in Brazilian sheep: physiological and blood parameters. Trop. Anim. Health Prod., v.41, p.95-101, 2009.

McMANUS, C.M.; FARIA, D.A.; LUCCI, C.M.; LOUVANDINI, H.; ALCANTRA, S.; Paiva, S.R. Heat stress effects on sheep: are hair sheep more heat resistant?. Theriogenology, v.155, p.157167, 2020.

POLIZOPOULOU, Z. Haematological tests in sheep health management. Small Ruminant Res., v.92, p.88-91, 2010.
REECE, W.O.; SWENSON, M.J. The composition and functions of blood. In: REECE, W.O. (Ed.). Dukes' physiology of domestic animals. Ithaca: Cornell University Press, 2004. p.26-52.

RESENDE, W.J.; BORGES, K.O.; LACERDA, D. Perfil hematológico de pacientes atendidos em uma clínica de medicina e segurança do trabalho no sul goiano. Rev. Bras. Hematol. Hemoter., v.35, p.42-43, 2013.

RIBEIRO, N.L.; PIMENTA FILHO, E.C.; ARANDAS, J.K.G. et al. Multivariate characterization of the adaptive profile in Brazilian and Italian goat population. Small Ruminant. Res., v.123, p.232-237, 2015.

SANTANA, A.M.; SILVA, D.G.; BERNARDES, P.A. et al. Hemograma e perfil bioquímico sérico de ovinos em idade de abate. Ciênc. Anim. Bras., v.1, p.286-289, 2009.

ŠIMPRAGA, M.; ŠMUC, T.; MATANOVIĆ, K. et al. Reference intervals for organically raised sheep: effects of breed, location and season on hematological and biochemical parameters. Small Ruminant Res., v.112, p.1-6, 2013.

THOM, E.C. The discomfort index. Weatherwise, v.12, p.57-59, 1959.

VOJTA, A.; SHEK-VUGROVEČKI, A.; RADIN, L. et al. Hematological and biochemical reference intervals in dalmatian pramenka sheep estimated from reduced sample size by bootstrap resampling. Vet. Arhiv, v.81, p.25-33, 2011.

YIĞIT, A.; KISA, Ü.; ARIKAN, Ş. et al. Influence of age and sex upon blood parameters in Sakiz X Karayaka G1 crossbred sheep. Ank. Univ. Vet. Fak., v.49, p.101-106, 2002. 